Article

\title{
Why is There No Tragedy in These Commons? An Analysis of Forest User Groups and Forest Policy in Bhutan
}

\section{Bill Buffum}

Department of Natural Resources Science, University of Rhode Island, Kingston, Rhode Island 02881, USA; E-Mail: buffum@uri.edu; Tel.: +1-401-874-7532; Fax: +1-401-874-4561

Received: 21 May 2012; in revised form: 21 June 2012 / Accepted: 3 July 2012 /

Published: 5 July 2012

\begin{abstract}
Governments around the world are increasingly devolving authority for forest management to the local level in an attempt to strengthen the management of national forests. Community forestry programs are recognized as providing a range of economic and social benefits and having a positive impact on increasing forest cover. However, concerns have been raised about the capability of user groups to manage community forests in a sustainable and equitable manner. This study analyzed the initial experience with community forestry in Bhutan and assessed the degree to which national policies have enhanced the likelihood of successful management by forestry user groups. The study found that the studied communities possess many attributes of successful forest user groups due to historical and socio-cultural reasons. National policies, including the unusual provision of handing over well-stocked forests to user groups, have further enhanced the likelihood of sustainable management by forest user groups. The initial experience of forest management by user groups in Bhutan is promising, and merits further study now that that a much larger number of community forests (CFs) have experience with harvesting.
\end{abstract}

Keywords: Bhutan; community forestry; forest policy; forest user groups

\section{Introduction}

In 1968 Garrett Hardin made the famous statement that "freedom in a commons brings ruin to all" ([1], p. 1244). Hardin argued that the users of a commons are caught in a process that eventually leads to the destruction of the resource upon which they depend, because each individual continues to 
use the resource until the expected costs of utilization equal the expected benefits. Since each individual does not consider the costs imposed on others, the accumulated individual decisions result in the overuse of the commons. Examples such as the desertification of the Sahel and deforestation of tropical forests appeared to confirm Hardin's predictions [2], and laboratory experiments produced a "tragedy of the commons" when users made independent and anonymous decisions about the use of common resources [3]. However, research during the last three decades has challenged the inevitability of the "tragedy of the commons" by documenting many examples of successful management of common property resources, and identifying the conditions under which individual users are more likely to decide that cooperative management is in their best interests [3].

Forest management provides an opportunity to study Hardin's theory. Property regimes in natural resources management can be divided into three classes: state property regimes, common property regimes, and individual property regimes [4]. Forests around the world are managed under all three classes of property regimes: it has been estimated that $77 \%$ of global forests are managed under state property regimes, $11 \%$ under common property regimes, and $12 \%$ under individual property regimes. In developing countries the percentage of forests under common property regimes is somewhat higher at $22 \%$, vs. $71 \%$ for state property regimes and $7 \%$ for individual property regimes [5].

Ironically, the nationalization of forests and the establishment of forest services in the 20th century sometimes created a "tragedy of the commons" by undermining traditional management systems. In Nepal, for example, "the new laws (related to forest nationalization)... led to widespread deforestation" ([6], p. 499). Many national forests are only occasionally monitored by government staff and in practice are open-access forests [7]. This situation also occurs in developed countries: nationalization of forests reportedly undermined local stewardship practices in Canada [8].

In an attempt to strengthen the management of national forests, governments around the world are increasingly devolving authority for forest management to the local level [9-11]. By 2002, governments had given communities legal rights to manage 380 million hectares of forest, $57 \%$ of which had been transferred during the previous 15 years [5]. This approach has been particularly widespread in South Asia. Nepal and India have the largest programs in the region: more than 13,000 forest user groups in Nepal are managing 25\% of the total national forests [12], while in India 53,000 Forest Protection Committees are managing 18\% of national forests [6]. The experience of Nepal and India in the 1980s and 1990s influenced forestry programs in many other countries [13], including Bhutan where the first community forest (CF) was handed over in 1997.

Community forestry programs are recognized as providing a range of economic and social benefits to the participating user groups [9-11], and having a positive impact on increasing forest cover [14-17]. However, many concerns have been raised about the capability of user groups to manage CFs in a sustainable manner $[5,8,11,18]$. There are examples of failed CFs: "members of some groups fail to perceive the growing scarcity of their local forests, fail to create effective rules to counteract the incentives to overharvest, and fail to enforce their own rules" ([19], p. 228). Many studies have documented equity problems in CFs: fewer benefits accruing to disadvantaged households [20,21]; favoritism by management committees in distributing products [22,23]; and rules that are biased towards meeting the needs of wealthier households [24,25].

In an attempt to understand why some forestry user groups are more successful than others, several authors have conducted multi-country studies to identify the attributes of successful user 
groups [2,26-28]. These attributes are of great interest to agencies developing or supporting community forestry programs; however, Agrawal concluded that this type of analysis is flawed due to obstacles such as "noncomparability of results from different studies, the problem of spurious correlation, and the difficulty of avoiding multiple and contingent causation in single case studies ([29], p. 1649).

Another complicating factor in studying forest governance relates to the indicators of success. The most common indictor of successful forest management is improved forest condition, which was used in recent analyses of forest governance in the Indian Himalaya [30] and Nepal [31]. However, other indicators of success, such as equity of benefit sharing or fulfillment of local needs may be equally important [27]. For example, some CFs in Nepal exhibit impressive increases in forest cover, but the benefits are limited and unfairly distributed among users, especially poor users who do not have access to forest products on private land [21].

This paper examines the initial experience of Bhutan's community forestry program, which was influenced by the established forestry programs of neighboring Nepal and India due to the strong links between the forestry professionals of the three countries. Bhutan's social, political and environmental conditions are quite different from its neighbors, and the country has developed its own unique policies and program. For example, the community forestry program of Bhutan is unusual in that well-stocked forests are handed over to user groups, whereas governments in many countries have only been willing to hand over degraded forests for community management $[10,11]$. Studies of the initial experience in Bhutan have reported that user groups were managing their forests sustainably and avoiding the problems with political and economic equity reported in Nepal and India [32-34]. This paper attempts to assess how national policies in Bhutan have contributed to sustainable and equitable forest management by user groups.

\section{Methodology}

This study expanded on a series of three studies that analyzed the experience of the first CFs in Bhutan to initiate timber harvesting activities. The previous studies focused on the sustainability of the harvesting approach utilized by user groups [32]; the sustainability of combining forest grazing and timber production in CFs [33], and the equity of decision making and distribution of CF benefits [34].

The first component of the current study assessed the degree to which the positive attributes of forest user groups identified by Ostrom [2] and McKean [26] apply in the context of Bhutan. The second component of the study assessed the degree to which the community forestry policies of Bhutan, as expressed in the Forest and Nature Conservation Rules [35] and the Community Forestry Manual [36], contributed to the success of the community forestry program by promoting these attributes. These two sets of positive attributes were selected for the current study because they focused exclusively on forestry user groups, unlike more recent studies by Ostrom [3] and Agrawal [29], and were more detailed than other recent analyses of forestry user groups [7,27,28,30]. Ostrom's list included the attributes of user groups and forests that are conducive to a community adopting or changing rules limiting access to their forests ([2], p. 4). These attributes are relevant to community forestry in Bhutan, because the local communities must initiate the process of forming a CF even though the government subsequently plays a significant role in supporting the user group. 
Based on the work by Ostrom and others, McKean developed a set of ten broad attributes of successful user groups [26].

The number of CFs that could be studied was very limited, as only three CFs had experience with harvesting timber at the time the field work was conducted. Therefore, the sample of CFs could not be assumed to be representative of all CFs in the country, even though it included $100 \%$ of the potential cases at the time. For this reason, a case study approach was used to develop the explanatory power of the findings. Supplemental data from 19 CFs that had not yet started harvesting operations were obtained through participatory rural appraisal (PRA) exercises which included focus group discussions with the user committees and members, and visits to the community forests.

A household survey provided detailed information on the use of the three CFs and the adjacent national forests. A random sample stratified by $\mathrm{CF}$ and socio-economic group included $29 \%(\mathrm{~N}=51)$ of the total 173 members of the three CFs. All members of the three CFs were categorized into four socio-economic groups to assess how the different socio-economic groups benefited from the CFs and participated in decision making. This was achieved through a wealth ranking exercise, which involved a team of five or more persons in each $\mathrm{CF}$, including the responsible extension agent and three or more community leaders. The criteria for the four socio-economic groups were established in consultation with the local community leaders and were based on a combination of the primary source of income, land and livestock holdings, size of house, and ownership of vehicles and mechanized equipment. The study addressed political equity by assessing three indicators developed in consultation with the CF members: representation on management committees; attendance in CF meetings; and knowledge about CF administration and finances. The study addressed economic equity by assessing five indicators based on access to the major products of the CFs and a sixth indicator related to the perception of having benefited from the CF: access to permits for timber and firewood trees; distance to marked trees; access to dry firewood collection; access to collection of NWFPs; access to forest grazing; and perception of personal benefits from the CF. Data on livestock holdings and grazing patterns were collected for the year the research was conducted and five years earlier. For more information about the wealth ranking process and equity indicators, see [34].

An important source of data was the lists of permits issued in the three CFs during the first three years of harvesting operations. The DOF introduced a standard process for CF management committees to maintain detailed records of permits issued for CF products [36]. The research team compiled the permits by household with the assistance of the committee members (the original permits were listed under the name of the individual who requested the permit rather than the CF member). Since this information was available for $100 \%$ of the members of the three user groups, statistical analysis of the data was not required. The data from the permit lists were verified during the household survey. In Yakpugang a detailed inventory of harvested and live trees was conducted to assess the impact of harvesting on the regeneration of preferred species [32].

Focus group discussions were conducted in the nearest adjacent village to each $\mathrm{CF}$ to collect additional information about the historical use of the forests. Each focus group discussion involved a group of farmers and local leaders, and followed a standard set of questions to assess whether the establishment of the CFs had a negative impact on villagers who were not members of the user groups. For example, traditional users could have been excluded from the user groups, or user groups could have protected their CFs at the cost of other national forests by moving livestock out of the CFs or 
requesting permits in other national forests. There has been speculation that the improved forest condition in some CFs in Nepal may have been partially offset by increased degradation of adjacent national forests $[37,38]$.

The three CFs are located in central and eastern Bhutan (Figure 1). Yakpugang Community Forest, in Mongar District has an area of 260 ha with an elevation range of 1800 to 3200 meters. The CF was formally handed over in May 2001 to 113 households. The forest is classified as cool broadleaved forest, and includes at least 32 genera of tree species dominated by Quercus, Castanopsis, Persea, Elaeocarpus and Symplocos. Masangdaza Community Forest, in Mongar District has an area of 87 ha and an elevation range of 690-980 m. The CF was formally handed over in August 2002 to 37 member households. Most of the $\mathrm{CF}$ is a well-stocked conifer forest dominated by Pinus roxburghii, but the CF also includes some broadleaved forest. Shambayung CF in Bumthang District has an area of 46.5 ha at an elevation of 3000-3500 m. The CF was handed over to 23 member households in August 2003. The CF includes a well-stocked conifer forest dominated by Pinus wallichiana.

Figure 1. Map of Bhutan study sites.

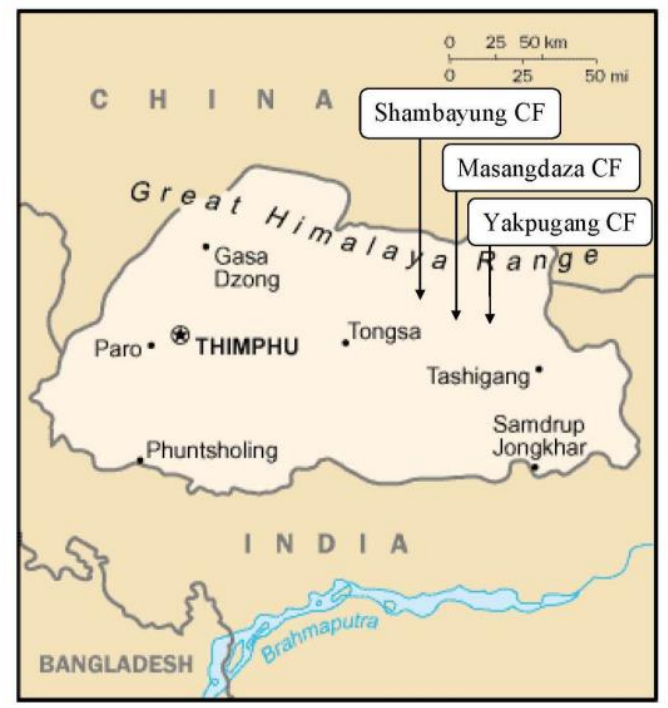

\section{Community Forestry in Bhutan}

Bhutan is a land-locked Himalayan country bordering with China (Tibet) and India, lying between the latitudes of $26^{\circ} 45^{\prime}$ and $28^{\circ} 10^{\prime}$ north and longitudes of $88^{\circ} 45^{\prime}$ and $92^{\circ} 10^{\prime}$ east. Bhutan has an area of 40,006 square kilometers and an estimated population of 672,425 [39]. At least nineteen languages in four major language groups are spoken by many different ethnic groups [40]. Elevation ranges from $100 \mathrm{~m}$ near the Indian border to $7554 \mathrm{~m}$ on the northern border with China. Bhutan has a rich biodiversity and is part of one of the ten global biodiversity 'hotspots' [41]. The country's biodiversity assets include 5446 species of vascular plants, of which 750 are endemic to the Eastern Himalayas and 50 are endemic to Bhutan itself; 770 species of birds; and 178 species of mammals [42]. Bhutan is well known for its commitment to conservation: $26 \%$ of the country has been set aside as protected areas [42].

Bhutan has a long standing tradition of local management of natural resources, which predates the unification of Bhutan in the 17th Century [43]. Before the nationalization of forests in 1969, villages had primary responsibility for forest management, and observed traditional practices that were similar 
in many ways to the current management of CFs. For example, many villages defined harvesting areas for exclusive use by community members for products such as firewood, bamboo, cane and other nontimber forest products [44]. Villages often marked traditional forest boundaries with cairns and collected fines when cattle from neighboring villages entered their forest [40].

The Department of Forests (DOF) was created in 1952 under the Ministry of Agriculture (MOA). In 1969 the government attempted to strengthen the management of Bhutan's forests by nationalizing all forests and introducing a system of issuing permits for the harvesting of timber and other forest products. The new forest policy retained some traditional rights in national forests, such individual or community rights to graze livestock in designated blocks of forest $[45,46]$ or collect leaf litter in designated blocks of forest [47-49], but eliminated the legal basis for many traditional practices of forest management related to timber and firewood production, including the exclusion of outsiders [50].

The development of Bhutan's community forestry program started in 1979 with the initiation of the national social forestry program. The legal framework for the program was outlined in the Forest and Nature Conservation Rules 2000 [51], and the first CF was legally handed over in 1997. The development of the program was given a boost in May 1993 when the Planning Commission of Bhutan recommended that the DOF decentralize some forestry activities to the district administrations. The DOF responded by assigning forestry extension staff to each district and giving them responsibility for a range of activities, including the new community forestry program [52]. Initially the Bhutan community forestry program was intended to be only implemented on degraded land, but in 1992 DOF decided to give villagers a stronger incentive to participate by stipulating that CFs should be approximately 50\% well-stocked and 50\% degraded [53,54].

After the approval of a CF management plan by DOF, a CF management committee elected by the members assumes responsibility for management of the $\mathrm{CF}$. The management committee organizes regular meetings of the users to implement the work plan for the coming period. An important activity in all $\mathrm{CFs}$ is patrolling to ensure that illegal harvesting or forest grazing is not taking place. In some $\mathrm{CFs}$, one or more forest guards are hired, while in other CFs the members take turns patrolling the forest on a voluntary basis. Other management activities include nursery management, tree-planting in degraded areas, thinning and tending operations, and creation of firelines. These activities are generally carried out on specified work days. Each member household must provide one person during the workdays, and members that do not participate are penalized with fines or assigned additional work.

When members require wood products, they request the management committee to issue a permit. The management committee verifies whether the member has already received his/her allocation of products, which is specified in the management plan. The management plans provide harvesting limits for each size class of timber. Other common products harvested in CFs include firewood, fence posts, flagpoles, and NWFPs such as bamboo, cane, wild vegetables, and medicinal plants. After issuing a permit using a standard permit book provided by DOF, a member of the CF management committee enters the forest with the applicant and marks the trees for harvesting with the official CF marking hammer, which leaves an imprint on the stump of the tree. After marking, the applicant harvests the trees at his/her convenience. Generally the members carry out some initial processing in the forest before transportation to the village. Most sawn timber is prepared with traditional pit saws, but recently villagers have started sawing boards with portable sawmills using a chainsaw frame attachment. Most harvesting and transportation is done by individuals, but groups of users often collaborate in harvesting 
and transporting firewood. The CFs generate income from royalty payments from the harvesting of wood products and contributions from visitors. The funds are used for a variety of purposes, including providing loans to members, constructing CF offices, providing meals during work days and meetings, and contributing to schools and temples.

The community forestry program is supported by an intensive forestry extension program. The ratio of government forestry extensionists to rural residents in 2000 was approximately 1:4000, based on a cadre of 117 forestry extension staff [55] and a rural population estimated to be $69 \%$ of the total population of 672,425 [39]. The 9th Five year Plan included an ambitious target to more than double the number of extension staff [55].

\section{Results}

\subsection{Analysis of Ostrom's Attributes}

The three studied CFs exhibited nine of Ostrom's eleven attributes that increase the likelihood of a community adopting or changing rules limiting access to its forests [3], and Bhutan's community forestry policy enhanced six of the attributes. The attributes are discussed below and summarized in Table 1.

Table 1. Summary of application of Ostrom's attributes to community forestry in Bhutan.

\begin{tabular}{lcc}
\hline Ostrom's attributes of user groups and forests & $\begin{array}{c}\text { Observed } \\
\text { in CFs }\end{array}$ & $\begin{array}{c}\text { Supported } \\
\text { by policy }\end{array}$ \\
\hline $\begin{array}{l}\text { O1. The forest should not be so degraded that it is useless to organize, or so } \\
\text { underutilized that there is little advantage from organizing. }\end{array}$ & Yes & Yes \\
\hline $\begin{array}{l}\text { O2. Reliable and valid information about the general condition of the } \\
\text { resource should be available at reasonable costs. }\end{array}$ & Yes & Yes \\
\hline O3. The availability of resource units should be relatively predictable. & Yes & Yes \\
\hline $\begin{array}{l}\text { O4. The resource should be sufficiently small, given the transportation and } \\
\text { communication technology in use, so that users can develop accurate } \\
\text { knowledge of external boundaries and internal microenvironments. }\end{array}$ & Yes & Yes \\
\hline $\begin{array}{l}\text { O5. Users should be dependent on the resource for a major portion of their } \\
\text { livelihood or other variables of importance to them. }\end{array}$ & Yes & Partially \\
\hline $\begin{array}{l}\text { O6. Users should have a shared image of the resource and how their actions } \\
\text { affect each other and the resource. }\end{array}$ & Yes & Yes \\
\hline $\begin{array}{l}\text { O7. Users should have a sufficiently low discount rate in relation to future } \\
\text { benefits to be achieved from the resource. }\end{array}$ & Yes & Yes \\
\hline $\begin{array}{l}\text { O8. Users with higher economic and political assets should be similarly } \\
\text { affected by a current pattern of use. }\end{array}$ & Yes & $\begin{array}{c}\text { Not directly } \\
\text { addressed }\end{array}$ \\
\hline $\begin{array}{l}\text { O9. Users should trust each other to keep promises and relate to one another } \\
\text { with reciprocity. }\end{array}$ & Yes & $\begin{array}{c}\text { Not directly } \\
\text { addressed }\end{array}$ \\
\hline $\begin{array}{l}\text { O10. Users should be able to determine access and harvesting rules without } \\
\text { external authorities countermanding them. }\end{array}$ & Yes & Partially \\
\hline $\begin{array}{l}\text { O11. Users should have learned at least minimal skills of organization through } \\
\text { participation in other local associations or learning from neighboring groups. }\end{array}$ & Yes & Partially \\
\hline
\end{tabular}


01. The forest should not be so degraded that it is useless to organize, or so underutilized that there is little advantage from organizing. All three CFs were well stocked with valuable timber trees with diameter at breast height ( $\mathrm{dbh}$ ) exceeding $50 \mathrm{~cm} \mathrm{dbh}$, based on the forest inventories conducted for each $\mathrm{CF}$ and our own visits to the forest. However, many users in all three CFs reported that they were concerned that over-harvesting could reduce the future availability of forest products, which gave them motivation to organize to manage the forest. The government policy supported this attribute by stating that where possible CFs should be composed of approximately 50\% degraded forest and $50 \%$ well-stocked forests [35].

O2. Reliable and valid information about the general condition of the resource should be available at reasonable costs. Our visits to the CFs revealed that the members were intimately familiar with the CFs, which they used regularly for forest grazing and harvesting timber and nonwood forest products. The CF members could easily identify all of the species of trees and NWFPs. Participation in the assessments gave them additional knowledge about the status of the forests. The government policy supported this attribute by including a participatory methodology for conducting forest inventories assessment as part of the management planning process, which required substantial involvement of the members.

O3. The availability of resource units should be relatively predictable. Our analysis of the timber permits revealed very limited year-to-year variation in the volume of timber harvested from the three CFs during the three year study period, which should result in a predictable supply of timber. The government policy supported this attribute by requiring that harvesting of timber does not exceed the annual allowable cut, which is calculated for each major size class of timber based on a detailed forest inventory, and never allows harvesting more than 5\% of the trees of any size class per year [36]. The government policy also requires a strict process for marking trees before felling and keeping records of all permits issued.

O4. The resource should be sufficiently small, given the transportation and communication technology in use, so that users can develop accurate knowledge of external boundaries and internal microenvironments. Our interviews revealed that most users could describe the boundaries and species composition in the different portions of their CFs. The number of hectares per household in the three studied CFs ranged from 2.02-2.35 ha/household, and the users could reach any part of their CFs by foot in one hour. The government policy supported this attribute by stipulating that the total area of each community forest should be limited to approximately 2.5 ha per user household.

O5. Users should be dependent on the resource for a major portion of their livelihood or other variables of importance to them. Most user group members (96\%) were dependent on the CFs for all of their timber, while $56 \%$ collected firewood in the CFs and 35\% collected NWFPs in the CFs. The exception was the in Yakpugang CF, where some users only utilized the CF for timber as it was more convenient for them to access another forest for forest grazing and non-wood forest products. The government policy partially addressed this attribute by requiring that user group members should be traditional users of the forest.

O6. Users should have a shared image of the resource and how their actions affect each other and the resource. Almost all of the users in the three CFs had been directly involved in the participatory rural appraisal (PRA) exercises and forest inventories that were conducted as part of the forest management planning process, which contributed to a shared image of the forest resources. 
During the interviews, the majority of the members were able to articulate how the forest condition had changed in recent years and what factors were responsible for the changes. Furthermore, almost all of the users $(96 \%)$ could articulate how they expected to benefit from the CFs in the future, with women more likely to consider all forest products as the primary future benefit of the $\mathrm{CF}$, and men more likely to focus exclusively on timber. The government policy supported this attribute by requiring the users to collaborate in a lengthy planning process and agree on the objectives of the CF.

07. Users should have a sufficiently low discount rate in relation to future benefits to be achieved from the resource. The three CFs provided the members with an immediate stream of benefits, which great lowered the discount rate in relation to future benefits. Furthermore, the users of all three CFs have lived in the area for a long time, and many mentioned the future availability of wood products for their children and grandchildren as a benefit of the CFs, which would further lower their discount rate. The government policy supported this attribute by handing over well-stocked forests and also by providing the users with secure rights to the forest that increase their confidence that they will continue to benefit over the long term from current investments in the forest.

O8. Users with higher economic and political assets should be similarly affected by a current pattern of use. The different socio-economic groups in the three CFs generally utilized the forest in similar ways, despite some minor differences. The poorest farmers were significantly more likely to have obtained timber from the CFs, and had equal access to firewood, NWFPs and forest grazing. Wealthier members were actually most affected by the ban on overnight grazing inside the CFs, as they had previously hired herders to live in the forest with their livestock. There were no indications that the CF rules were biased towards meeting the needs of wealthier members. Most users from all socio-economic groups were primarily interested in having a sustainable supply of timber from the CFs. The government policy did not specifically address this issue.

09. Users should trust each other to keep promises and relate to one another with reciprocity. The level of trust and cooperation within the user groups appeared to be high: there were no allegations of misuse of funds or complaints about the management of the CFs. Participation in CF meetings was high: $80 \%$ of the users had attended the last CF meeting, with no significant differences between male and female members. Distribution of benefits from the CF was highly equitable, with poorer members more likely to have received timber than the richer members. The membership of the management committees included a mix of poor and rich members. The CFs required members to contribute voluntary labor for forest management activities, but only one respondent reported difficulty in providing the required voluntary labor. All of the users interviewed were clear on how they benefit from the $\mathrm{CF}$, and seemed highly satisfied with the experience to date of being a member of the CF. The government policy did not specifically address this issue.

010. Users should be able to determine access and harvesting rules without external authorities countermanding them. The three CFs had considerable flexibility in determining where to harvest trees within the CFs, but the DOF reviews the harvesting records and visits the CF regularly to ensure that harvesting does not exceed the amount determined to be sustainable by the forest resources assessment. The government policy partially supported this attribute by allowing the users to determine the harvesting rules as long as the total harvesting level was no higher than the annual allowable cut determined by the forest inventory as part of the management planning process. 
O11. Users should have learned at least minimal skills of organization through participation in other local associations or learning from neighboring groups. We observed that the $\mathrm{CF}$ committees were skilled at calling meetings and coming to consensus on key issues. Participation in meetings was high: $80 \%$ of the users had attended the last CF meeting, with no significant differences between male and female members. However, the financial and record keeping skills of the users were weak, despite considerable amounts of training provided by DOF during the management planning process and after the handover. The government policy partially supported this attribute by including skill development activities for the users in the management planning process.

\subsection{Analysis of McKean's Attributes}

The three studied CFs exhibited nine of McKean's ten attributes of successful user groups attributes. The attributes are discussed below and summarized in Table 2. The analysis of Bhutan's community forestry program policy found that the government policy supported nine of the ten attributes.

Table 2. Summary of analysis of McKean's attributes to community forestry in Bhutan.

\begin{tabular}{lcc}
\hline McKean's attributes of successful user groups & $\begin{array}{c}\text { Observed } \\
\text { in CFs }\end{array}$ & $\begin{array}{c}\text { Supported } \\
\text { by policy }\end{array}$ \\
\hline $\begin{array}{l}\text { M1. User groups need the right to organize or at least no interference } \\
\text { in their attempt to organize. }\end{array}$ & Yes & Yes \\
\hline M2. The boundaries of the resources must be clear. & Yes & Yes \\
\hline M3. Criteria for membership in the user group must be clear. & Yes & Yes \\
\hline M4. Users must have the right to modify their use rules over time. & Yes & Yes \\
\hline $\begin{array}{l}\text { M5. Use rules should be environmentally conservative to provide a } \\
\text { margin for error. }\end{array}$ & Yes & Yes \\
\hline M6. Use rules must be clear and easily enforceable. & Yes & Yes \\
\hline M7. Infractions of rules must be monitored and punished. & Yes & Yes \\
\hline $\begin{array}{l}\text { M8. Decision making and distribution of benefits need not be } \\
\text { egalitarian, but must be viewed by the members as "fair" }\end{array}$ & Yes & Yes \\
\hline M9. Inexpensive and rapid methods are needed for conflict resolution & Yes & Yes \\
\hline $\begin{array}{l}\text { M10. Institutions for managing very large systems need to be layered } \\
\text { with devolution of authority to small components to give them } \\
\text { flexibility and control over their fate. }\end{array}$ & Irrelevant & No \\
\hline
\end{tabular}

M1. User groups need the right to organize or at least no interference in their attempt to organize. The users of the three CFs were aware of their legal standing, which was also acknowledged during interviews with government officials and neighboring communities. The government policy supported this attribute by giving clear legal standing to CF user groups.

M2. The boundaries of the resources must be clear. Our field visits revealed that the boundaries of the three CFs were clearly marked, and members were aware of the boundaries. The government policy supported this attribute by requiring that the boundary of the CF must be surveyed and marked.

M3. Criteria for membership in the user group must be clear. Membership in the three CFs was open to all residents of the villages near the CFs, and our interviews in adjacent villages did not reveal 
any indications that traditional users from other villages had been excluded. The government policy supported this attribute by requiring that all traditional users of the forest must be allowed to join.

M4. Users must have the right to modify their use rules over time. The users of all three CFs are aware that they have the right to modify their rules. Yakpugang CF was in the process of revising the management plan to: (a) include additional areas for firewood collection, and (b) adjust the rules for primary and secondary members. Masangdaza CF had already adopted new rules to allow users who missed work days to provide additional labor rather than paying cash fines. The government policy supports this attribute by stating that management plans can be revised as necessary and providing strong support through the forestry extension service during the revision process.

M5. Use rules should be environmentally conservative to provide a margin for error. We observed that the harvesting limits in the three CFs for each size class of timber and firewood were based on the forest inventories, and were conservatively calculated following DOF guidelines to maximize sustainability of production. The government policy supports this attribute by requiring that harvesting limits are based on a detailed forest inventory conducted during the management planning process, and never allowing harvesting more than 5\% of the trees of any size class per year [36]. Furthermore, harvesting limits must be expressed in terms of number of trees rather than wood volume, in order to be more easily understood by the users [36].

M6. Use rules must be clear and easily enforceable. The management plans of the three CFs included detailed rules for harvesting which we observed were understood by the members. The government policy states that each management plan must include a detailed set of rules for use of the CF.

M7. Infractions of rules must be monitored and punished. The users of the CFs were aware that they have the right to punish infractions of rules. All of the management plans specify fines for different infractions. Two of the three CFs had imposed fines on members for unauthorized harvesting or grazing, or for lack of attendance at work days. The government policy states that the CF management committee has the right to impose fines.

M8. Decision making and distribution of benefits need not be egalitarian, but must be viewed by the members as "fair". The members of all three CFs reported that the distribution of products had been fair. The poorest farmers were significantly more likely to have obtained timber from the CFs, and had equal access to firewood, NWFPs and forest grazing. However, the awareness of many members about CF administration and financial management was limited, which could lead to inequitable distribution in the future. For example, only $18 \%$ of the members knew how much money was currently in the CF fund, and only 19\% could explain how the fund was intended to be used. The government policy requires that user groups follow a detailed process for issuing permits for CF products, and the user groups must submit reports on annual harvesting using a standard monitoring format.

M9. Inexpensive and rapid methods are needed for conflict resolution. The management plans for each CF included a section on conflict management. At the time of the study there were not yet many examples of conflict resolution; however, the Yakpugang members decided to replace their management committee after three years because the committee members were not considered to be sufficiently available to perform duties such as issuing permits and marking trees on a timely basis. The government policy states that management plans must include a section on conflict resolution. 
M10. Institutions for managing very large systems need to be layered with devolution of authority to small components to give them flexibility and control over their fate. This attribute was not relevant for the three CFs. The government policy does not specifically address this issue, but so far there have not been any expressions of interest in establishing a very large CF in Bhutan. At the time of the study, the largest CF contained 300 ha and the largest membership was 126 households.

\section{Discussion}

This study analyzed the initial experience of Bhutan's community forestry program to assess: (a) the extent to which community forest user groups exhibit the positive attributes identified by Ostrom [2] and McKean [26]; and (b) the extent to which national forestry policies have contributed to the success of Bhutan's community forestry program. The CFs exhibited most of Ostrom's and McKean's positive attributes, which can be partially attributed to historical and socio-cultural factors that are conducive to successful user group management. However, the government of Bhutan appears to have provided strong support to the community forestry program by adopting effective community forestry policies such as handing over well-stocked forests to user groups and providing an intensive forestry extension service.

Traditional Forest Management Practices: Bhutan has a long standing tradition of local forest management, which may have enhanced the capability of the new user groups. Before the nationalization of forests in 1969, villages observed traditional practices that were similar in many ways to the current management of CFs. For example, many villages defined harvesting areas for exclusive use by community members for products such as firewood, bamboo, cane and other nontimber forest products [44], and marked traditional forest boundaries with cairns and collected fines when cattle from neighboring villages entered their forest [40]. Often a specific person was given authority to serve as a forest protector and ensure proper distribution of fuelwood and timber for construction [56]. Even though the nationalization of forests in 1969 eliminated the legal basis for these traditional practices, many continued throughout the country and other traditional practices remained legal, such as forest grazing [45,46] and production of leaf litter [49]. This traditional forest management experience would have provided the users with skills that could be applied to the management of the CFs (attribute O11).

Socio-cultural conditions: Each of the three studied user groups was ethnically homogenous, shared a common language and did not observe the caste system, which may have enhanced positive attributes such as trusting each other (attribute O9) and viewing distribution of benefits as "fair" (attribute O8). The wealthier community members in Bhutan generally utilized the forest in the same ways as the poorer members and had similar long term interests in managing the forest (attribute 08). Ostrom noted that powerful members can enhance the probability of successful organization when they have similar long term interests as other community members [2]. The status of women in Bhutan may have also been a positive factor. More than half (51\%) of the members of the three studied CFs were female. Greater involvement of women in decision making has been correlated to improved forest condition because women can make sound management decisions due to their strong involvement in the collection of forest products [30]. The findings in Bhutan contrast with other 
countries, where ethnic heterogeneity has contributed to inequity [37,57-60] and fewer women participated in CF user groups [6].

Hand-over of well stocked forests: Perhaps the most unusual aspect of Bhutan's community forestry program is the willingness of the government to hand over well-stocked forests to communities. All three CFs contained valuable timber-size trees, which were being actively harvested by the communities. This provided the user groups with an immediate and significant benefit stream, and contributed to many of the positive attributes. Obtaining valuable products from the CFs lowered their discount rate in relation to future benefits from the CFs (attribute O7), and more importantly increased the level of trust as it became evident that the poor members would benefit as much as the richer members (attribute O9). It also gave them experience with determining harvesting rules (O10) and developing their organization skills to issue permits and maintain the required records $(\mathrm{O} 11)$.

Ostrom noted that communities are more willing to adopt rules to limit access to forests resources when the forest is not so degraded that it is useless to organize or so underutilized that there is little advantage from organizing (attribute O1). Even though the CFs were well-stocked by international standards, the users were concerned that over-harvesting could reduce the future availability of forest products, which gave them motivation to organize to management the forest. Interestingly, in all three cases they were most concerned about legal harvesting by outsiders with permits from the DOF. The three CFs were all located close to roads, which greatly increased the feasibility of outsiders transporting the timber by road to their residences. This situation is not unusual in Bhutan - most of the other $19 \mathrm{CFs}$ visited shared the same concerns.

Governments in many countries have only been willing to hand over degraded forests for community management [10,11]. For example, forest policies in Nepal since 2000 have restricted the handover of well-stocked forests in the Terai/Churia regions while continuing to promote the handover of relatively low value forests in the mid-hills [6,61]. In India, the Forest Department reportedly retained control of the most productive forest land and allocated fragmented and degraded patches for community management [6]. In Bhutan, however, the government decided to give villagers a stronger incentive to participate by stipulating that CFs should be approximately 50\% well-stocked and 50\% degraded [53,54]. This provision was probably influenced by the abundance of forest resources: although Bhutan has only $60 \%$ as much per capita agriculture land as Nepal and $46 \%$ as much of India, the country has eight times the per capita forest land of Nepal and more than 22 times the per capita forest land of India [62]. However, the policy probably reflected a genuine willingness to give up control of some national forests in order to promote economic development at the village level. When Bhutan's Forest and Nature Conservation Rules were amended in 2006 [63], the stipulation about CFs being approximately 50\% well-stocked was deleted. It remains to be seen how much impact this will have on the future hand-over of well-stocked CFs.

Intensive forestry extension: Bhutan's intensive forestry extension program was another important factor that affected several attributes. The three forestry extension agents responsible for the studied CFs lived within a few $\mathrm{km}$ of the sites and had regular contact with the user groups. They provided strong support during the management planning phase, which relied heavily on participatory rural appraisal (PRA) exercises to increase the involvement and awareness of the users. This would have contributed to a shared image of the resource (attribute O6). The extension agents also worked closely with the users to introduce a set of standardized monitoring formats that provides the users with 
reliable indicators about the condition of the forest (attribute O2), which would allow them to adapt quickly to changes that affect their future benefits [2]. The monitoring system also enabled the users to monitor their own compliance with the rules, which has been identified as being a key attribute of successful user groups [64]. The management plans provided clear guidance on harvesting limits of different size classes, which contributes to use rules being environmentally conservative (attribute M5) and easily enforceable (attribute M6), which may explain why harvesting did not exceed the annual allowable cut during the first three years of harvesting.

Many authors have stressed the importance of strong extension support for community forestry programs. Menzies ([10], p. 26) analyzed six reviews of community based forest management around the world and noted the importance of "crafting and building community institutions which can ensure equitable, inclusive and just governance with mechanisms to counter the possibility of corruption and elite domination." Nurse et al. [65] highlighted the importance of extension support in Bhutan during the management planning process in order to avoid subsequent equity problems.

\section{Conclusions}

Hardin's "tragedy of the commons" has been observed in some forest management regimes, even CFs that in theory should be able to avoid this fate. However the initial experience with community forestry in Bhutan supports Ostrom's conclusion that "tragedies of the commons are real but not inevitable" ([66], p. 280). Due to historical and socio-cultural reasons, communities in Bhutan possess many attributes of successful forest user groups. As a result they are more likely to determine that cooperative management of forests is in their best interests, and adopt rules controlling access. National policies for community forestry, including the unusual provision of handing over well-stocked forests to user groups, have further enhanced the likelihood of communities forming effective forestry user groups and managing their CFs sustainably and equitably. The initial experience of forest management by user groups in Bhutan is promising, and merits further study now that that a much larger number of CFs have experience with harvesting.

\section{Acknowledgments}

This research was conducted with inputs from many staff members of the Ministry of Agriculture of Bhutan and other agencies. Special thanks to Yeshi Tenzin, Shacha Dorji, Namkha Gyeltshen, KJ Temphel, Georg Gratzer, Anna Lawrence, the management committees of the studied CFs, and the three anonymous reviewers. Funding for the research was provided by the Swiss Agency for Development and Cooperation (SDC) and Helvetas.

\section{Conflict of Interest}

The author declares no conflict of interest. 


\section{References}

1. Hardin, G. The tragedy of the commons. Science 1968, 162, 1243-1248.

2. Ostrom, E. Self-Governance and Forest Resources; Cifor Occasional Paper No. 20; CIFOR: Jakarta, Indonesdia, February 1999; p. 15.

3. Ostrom, E. A diagnostic approach for going beyond panaceas. Proc. Natl. Acad. Sci. 2007, 104, $15181-15187$.

4. Bromley, D.W. Arresting renewable resource degradation in the third world: Discussion. Am. J. Agric. Econ. 1990, 72, 1274-1275.

5. White, A.; Martin, A. Who Owns the World's Forests? Forest Tenure and Public Forests in Transition; Center for International Environmental Law: Washington, DC, USA, 2002; p. 30.

6. Agrawal, A.; Ostrom, E. Collective action, property rights, and decentralization in resource use in India and Nepal. Polit. Soc. 2001, 29, 485-514.

7. Nagendra, H. Drivers of reforestation in human-dominated forests. Proc. Natl. Acad. Sci. 2007, 104, 15218-15223.

8. Roberts, E.H.; Gautam, M.K. Community Forestry Lessons for Australia: A Review of International Case Studies; The Australian National University: Canberra, Australia, February 2003; p. 16.

9. Lawrence, A. Beyond the second generation: Towards adaptiveness in participatory forest management. Vet. Sci. Nutr. Nat. Resour. 2007, 2, 1-15.

10. Menzies, N.K. 'Global Gleanings' Lessons from Six Studies of Community Based Forest Management, Report for Ford Foundation's Environment and Development Affinity Group (EDAG); Ford Foundation: Berkley, MI, USA, 2002.

11. Carter, J. Recent Experience in Collaborative Management; Cifor Occasional Paper No. 43; Centre for International Forestry Research: Bogor, Indonesia, 2005.

12. Pokharel, B.K.; Paudel, D. Impacts of armed conflicts on community forest user groups in Nepal: Can community forestry survive and contribute to peace building at local level? Eur. Trop. For. Res. Netw. 2005, 43/44, 83-86.

13. Hobley, M. Building State-People Relationships in Forestry; Forest Policy and Environment Programme, Overseas Development Institute: London, UK, November 2005; p. 7.

14. Gautam, A.P.; Shivakoti, G.P.; Webb, E.L. Forest cover change, physiography, local economy, and institutions in a mountain watershed in Nepal. Environ. Manag. 2004, 33, 48-61.

15. Gautam, A.P.; Webb, E.L.; Eiumnoh, A. GIS assessment of land use/land cover changes associated with community forestry implementation in the middle hills of Nepal. Mt. Res. Dev. 2002, 22, 63-69.

16. Sakurai, T.; Rayamajhi, S.; Pokharel, R.K.; Otsuka, K. Efficiency of timber production in community and private forestry in Nepal. Environ. Dev. Econ. 2004, 9, 539-561.

17. Yadav, N.P.; Dev, O.P.; Springate-Baginski, O.; Soussan, J. Forest management and utilization under community forestry. J. For. Livelihood 2003, 3, 37-50.

18. Kellert, S.R.; Mehta, J.N.; Ebbin, S.A.; Lichtenfeld, L.L. Community natural resource management: Promise, rhetoric, and reality. Soc. Nat. Resour. 2000, 13, 705-715. 
19. Gibson, C.C.; McKean, M.A.; Ostrom, E. Some Initial Theoretical Lessons. In People and Forests: Communities, Institutions, and Governance; Gibson, C.C., McKean, M.A., Ostrom, E., Eds.; MIT Press: Cambridge, MA, USA, 2000; pp. 227-242.

20. McDermott, M.H.; Schreckenberg, K. Equity in Community Forestry: Insights from North and South. Int. For. Rev. 2009, 11, 157-170.

21. Shrestha, K.K.; McManus, P. The politics of community participation in natural resource management: Lessons from community forestry in Nepal. Aust. For. 2008, 71, 135-146.

22. Springate-Baginski, O.; Dev, O.P.; Yadav, N.P.; Soussan, J. Community forest management in the middle hills of Nepal: The changing context. J. For. Livelihood 2003, 3, 5-10.

23. Varalakshmi, V. Joint Forest Management and Conflict in Haryana, India. In Community-Based Forest Resource Conflict Management; Means, K., Josayma, C., Eds.; Food and Agriculture Organization, United Nations: Rome, Italy, 2002; Volume 1, p. 321.

24. Adhikari, B. Poverty, property rights and collective action: Understanding the distributive aspects of common property resource management. Environ. Dev. Econ. 2005, 10, 7-31.

25. Schreckenberg, K.; Luttrell, C.; Moss, C. Participatory Forest Management: An Overview; Forest Policy and Environment Programme, Overseas Development Institute: London, UK, March 2006.

26. McKean, M.A. Common Property: What Is It, What Is It Good for, and What Makes It Work? In People and Forests : Communities, Institutions, and Governance; Gibson, C.C., McKean, M.A., Ostrom, E., Eds.; MIT Press: Cambridge, MA, USA, 2000; pp. 27-55.

27. Pagdee, A.; Kim, Y.-S.; Daugherty, P.J. What makes community forest management successful: A meta-study from community forests throughout the world. Soc. Nat. Resour. 2006, 19, 33-52.

28. Persha, L.; Agrawal, A.; Chhatre, A. Social and ecological synergy: Local rulemaking, forest livelihoods, and biodiversity conservation. Science 2011, 331, 1606-1608.

29. Agrawal, A. Common property institutions and sustainable governance of resources. World Dev. 2001, 29, 1649-1672.

30. Agrawal, A.; Chhatre, A. Explaining success on the commons: Community forest governance in the Indian Himalaya. World Dev. 2006, 34, 149-166.

31. Nagendra, H. Tenure and forest conditions: Community forestry in the Nepal terai. Environ. Conserv. 2002, 29, 530-539.

32. Buffum, B.; Gratzer, G.; Tenzin, Y. The sustainability of selection cutting in a late successional broadleaved community forest in Bhutan. For. Ecol. Manag. 2008, 256, 2084-2091.

33. Buffum, B.; Gratzer, G.; Tenzin, Y. Forest grazing and natural regeneration in a late successional broadleaved community forest in Bhutan. Mt. Res. Dev. 2009, 29, 30-35.

34. Buffum, B.; Lawrence, A.; Temphel, K.J. Equity in community forests in Bhutan. Int. For. Rev. 2010, 12, 187-199.

35. DOF. Forest and Nature Conservation Rules of Bhutan, 2003; Department of Forests, Ministry of Agriculture, Royal Government of Bhutan: Thimphu, The Kingdom of Bhutan, 2003.

36. DOF. Community Forestry Manual for Bhutan; Social Forestry Division, Department of Forests, Ministry of Agriculture, Royal Government of Bhutan: Thimphu, The Kingdom of Bhutan, 2004.

37. Chhetry, B.; Francis, P.; Gurung, M.; Iversen, V.; Kafle, G.; Pain, A.; Seely, J. A framework for the analysis of community forestry performance in the terai. J. For. Livelihood 2005, 4, 1-16. 
38. Pokharel, B.; Nurse, M. Forest and people's livelihood: Benefiting the poor from community forestry. J. For. Livelihood 2004, 4, 19-30.

39. RGOB. Results of Population and Housing Census of Bhutan 2005; Office of Census Commissioner, Royal Government of Bhutan: Thimphu, The Kingdom of Bhutan, 2005.

40. Wangchuk, T. Change in the land use system in Bhutan: Ecology, history, culture, and power. $J$. Bhutan Stud. 2000, 12, 54-85.

41. Myers, N.; Mittermeier, R.A.; Mittermeier, C.G.; da Fonseca, G.A.B.; Kent, J. Biodiversity hotspots for conservation priorities. Nature 2000, 403, 853-858.

42. DOF. Forestry in Bhutan-Facts and Figures; Department of Forestry Services, Ministry of Agriculture, Royal Government of Bhutan: Thimphu, The Kingdom of Bhutan, 2002.

43. Ura, K. Peasantry and Bureaucracy in Decentralisation in Bhutan; Discussion Paper No. 17; Institute of Developing Economies (IDE): Thimphu, The Kingdom of Bhutan, December 2004.

44. DRDS. A Framework for Community-Based Natural Resources Management in Bhutan-Summary; Department of Research and Development Services, Ministry of Agriculture, Royal Government of Bhutan: Thimphu, The Kingdom of Bhutan, 2002; p. 47.

45. Ura, K. The herdsmen's dilemma. J. Bhutan Stud. 2002, 7, 61-81.

46. Roder, W.; Gratzer, G.; Wangdi, K. Cattle grazing in the conifer forests of Bhutan. Mt. Res. Dev. 2002, 22, 368-374.

47. Dorji, L.; Webb, E.L.; Shivakoti, G. Can a nationalised forest management system uphold local institutions? The case of leaf litter forest (sokshing) management in Bhutan. Asian Stud. Rev. 2003, 27, 341-359.

48. Dorji, L.; Webb, E.L.; Shivakoti, G.P. Forest property rights under nationalized forest management in Bhutan. Environ. Conserv. 2006, 33, 141-147.

49. Webb, E.L.; Dorji, L. Efficiency and Low Costs under Non-limiting Supply Conditions in Bhutan. In Promise, Trust, and Evolution: Managing the Commons of South Asia; Ghate, R., Jodha, N., Mukhopadhyay, P., Eds.; Oxford University Press: Oxford, UK, 2008.

50. Messerschmidt, D.; Temphel, K.J.; Davidson, J.; Incoll, W.D. Bamboo in the High Forest of Eastern Bhutan-A Study of Species Vulnerability; International Centre for Integrated Mountain Development (ICIMOD): Kathmandu, Nepal, 2001; p. 32.

51. DOF. Forest and Nature Conservation Rules 2000; Department of Forests, Ministry of Agriculture, Royal Government of Bhutan: Thimphu, The Kingdom of Bhutan, 2000.

52. MOA. Implementation Guidelines for Decentralized Forestry Activities-Working Draft; Social Forestry \& Extension Section, Forest Services Division, Department of Forests, Ministry of Agriculture, Royal Government of Bhutan: Thimphu, The Kingdom of Bhutan, January 1997.

53. Chhetri, B.B. Review of Experiences of Social Forestry and Forestry Extension in Bhutan; Social Forestry and Forestry Extension-Report of the National Workshop on Social Forestry and Forestry Extension, Lingmethang, January 1992; UNDP/FAO Forest Resources Management and Institutional Development Project, Ministry of Agriculture, Royal Government of Bhutan: Lingmethang, The Kingdom of Bhutan, 1993; pp. 14-29. 
54. Upadhyay, K. Review of Community Forest/Community Protected Forest Rules; Social Forestry and Forestry Extension-Report of the National Workshop on Social Forestry and Forestry Extension, Lingmethang, January 1992; UNDP/FAO Forest Resources Management and Institutional Development Project, Department of Forestry, Ministry of Agriculture, Royal Government of Bhutan: Lingmethang, The Kingdom of Bhutan, 1993; pp. 92-103.

55. DOF. Forest Sub-Sector Plan-Ninth Five-Year Plan (2002-2007); Department of Forests, Ministry of Agriculture, Royal Government of Bhutan: Thimphu, The Kingdom of Bhutan, 2002.

56. Penjore, D.; Rapten, P. Trends of Forestry Policy Concerning Local Participation in Bhutan. In Policy Trend Report 2004; Harada, K., Nanang, M., Eds.; Institute for Global Environmental Strategies: Kanagawa, Japan, 2004; pp. 21-27.

57. Adhikari, B.; Di Falco, S.; Lovett, J.C. Household characteristics and forest dependency: Evidence from common property forest management in Nepal. Ecol. Econ. 2004, 48, 245-257.

58. Malla, Y.; Neupane, H.R.; Branney, P.J. Why aren't poor people benefiting more from community forestry? J. For. Livelihood 2003, 3, 78-90.

59. Nightingale, A. Nature-society and development: Social, cultural and ecological change in Nepal. Geoforum 2003, 34, 525-540.

60. Uprety, D.R. Conflicts in natural resource management-Examples from community forestry. Jahrb. Österreichischen Ges. Agrarökonomie 2006, 15, 143-155.

61. Bhattarai, B. Widening the Gap between Terai and Hill Farmers in Nepal: The Implications of the New Forest Policy 2000. In Hanging in the Balance: Equity in Community-Based Natural Resource Management in Asia; Mahanty, S., Fox, J., Nurse, M., Stephen, P., McLees, L., Eds.; RECOFTC and East-West Center: Bangkok, Thailand, 2006; pp. 143-161.

62. WRI. Country Profiles; World Resources Institute: Washington, DC, USA, 2007.

63. DOF. Forest and Nature Conservation Rules of Bhutan, 2006; Department of Forests, Ministry of Agriculture, Royal Government of Bhutan: Thimphu, The Kingdom of Bhutan, 2006. Available online: http://www.moaf.gov.bt/moaf/?p=33\&wpfb_cat=8 (accessed on 20 May 2012).

64. Gibson, C.C.; Williams, J.T.; Ostrom, E. Local enforcement and better forests. World Dev. 2005, 33, 273-284.

65. Nurse, M.; Robinson, P.; Paudel, D.; Pokharel, B. Towards Pro-Poor Community Forestry—Recent Experiences from Dolakha and Okhaldunga Districts; Timsina, N.P., Ojha, H.R., Eds.; National Workshop on Management of Common Property Resources and Equity: Exploring Lessons from Nepal, Kathmandu, Nepal, 2003; pp. 41-63.

66. Ostrom, E.; Burger, J.; Field, C.B.; Norgaard, R.B.; Policansky, D. Revisiting the commons: Local lessons, global challenges. Science 1999, 284, 278-282.

(C) 2012 by the author; licensee MDPI, Basel, Switzerland. This article is an open access article distributed under the terms and conditions of the Creative Commons Attribution license (http://creativecommons.org/licenses/by/3.0/). 